\title{
Laser Welding Beam Quality Calibration
}

Federal Manufacturing \& Technologies

L. R. Foulk

KCP-613-5954

Published June 1997

RECEIVED

JUL $1^{4} 1007$

OSTI

Final Report

Approved for public release; distribution is unlimited.
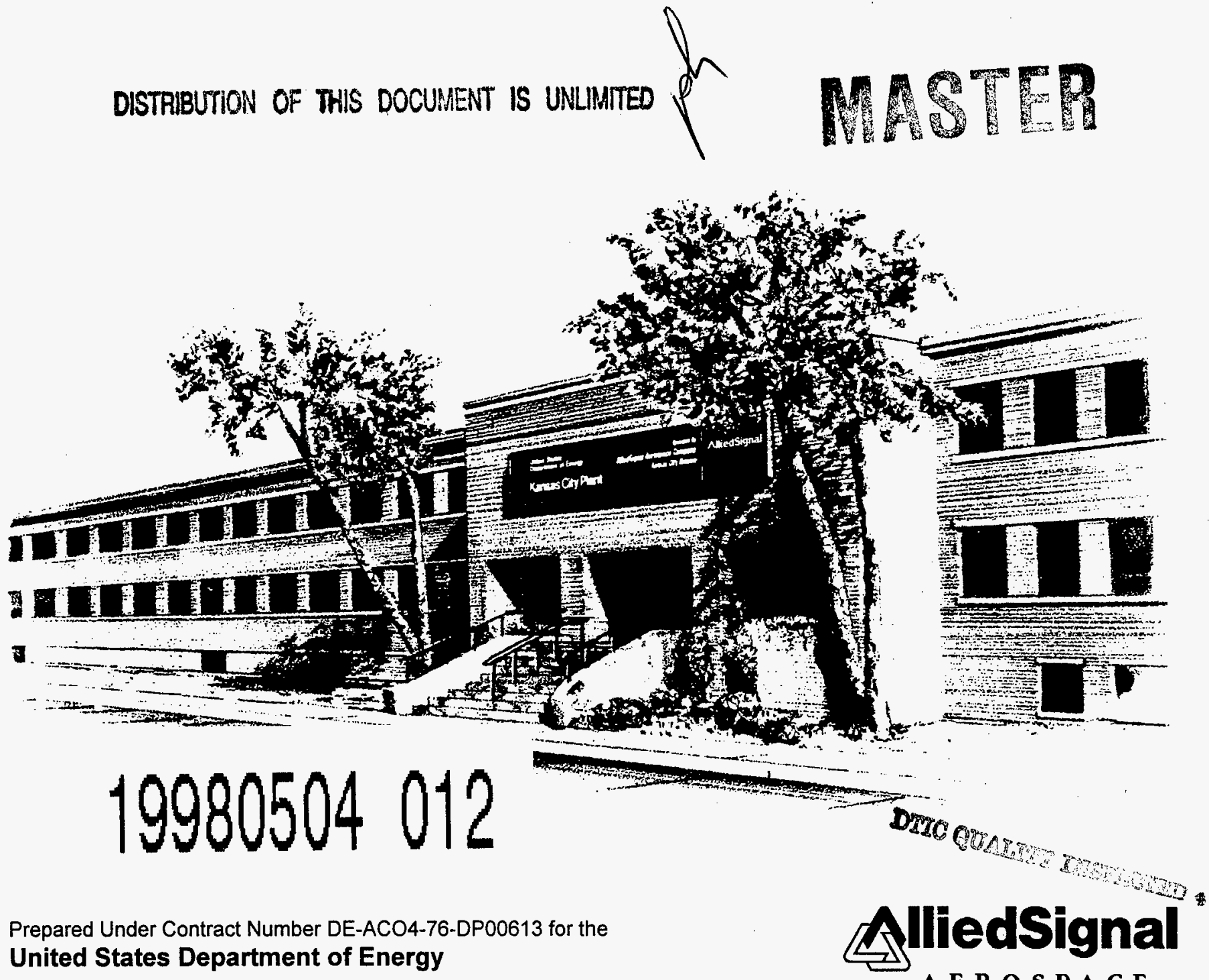


\section{DISCLAIMER}

This report was prepared as an account of work sponsored by an agency of the United States Government. Neither the United States Government nor any agency thereof, nor any of their employees, makes any warranty, express or implied, or assumes any legal liability or responsibility for the accuracy, completeness, or usefulness of any information, apparatus, product, or process disclosed, or represents that its use would not infringe privately owned rights.. The views and opinions of authors expressed herein do not necessarily state or reflect those of the United States Government or any agency thereof.

All data prepared, analyzed and presented has been developed in a specific context of work and was prepared for internal evaluation and use pursuant to that work authorized under the referenced contract. Reference herein to any specific commercial product, process or service by trade name, trademark, manufacturer, or otherwise, does not necessarily constitute or imply its endorsement, recommendation, or favoring by the United States Government, any agency thereof or AlliedSignal Inc.

Printed in the United States of America.

This report has been reproduced from the best available copy.

Available to DOE and DOE contractors from the Office of Scientific and Technical Information, P. O. Box 62, Oak Ridge, Tennessee 37831; prices available from (615) 576-8401, FTS 626-8401.

Available to the public from the National Technical Information Service, U. S. Department of Commerce, 5285 Port Royal Rd., Springfield, Virginia 22161.

A prime contractor with the United States Department of Energy under Contract Number DE-ACO4-76-DP00613.
AlliedSignal Inc. Federal Manufacturing \& Technologies P. O. Box 419159 Kansas City, Missouri 64141-6159 
Approved for public release; distribution is unlimited.

\section{LASER WELDING BEAM QUALITY CALIBRATION}

L. R. Foulk

Published June 1997

Final Report

L. R. Foulk, Project Leader

Project Team:

Eric Burkhardt

Jim Cummins

Don Hollar

Jose Samayoa

Harold Strifler

Leonard Wonnell 


\section{CONTENTS}

Section

Page

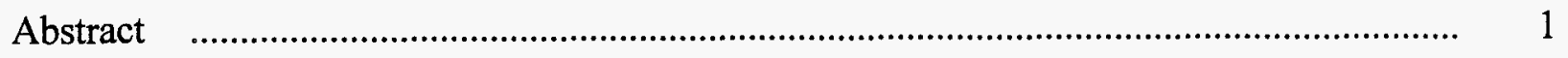

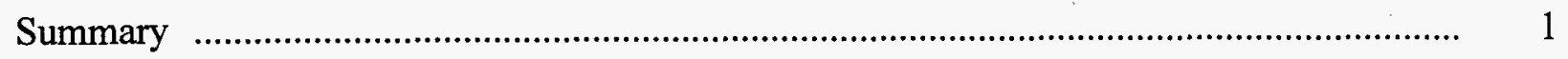

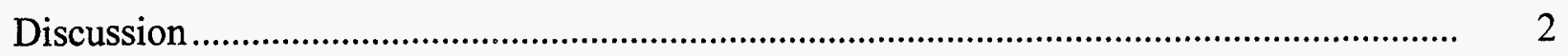

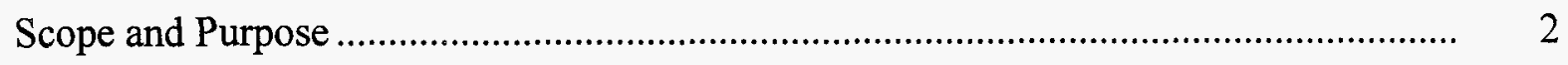

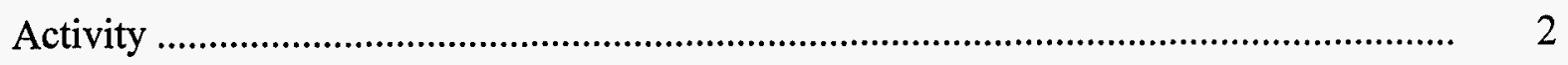

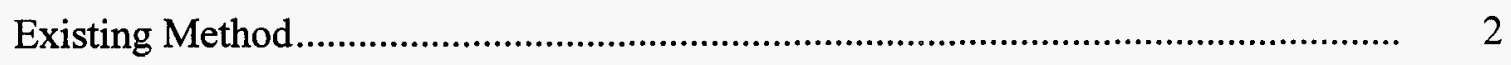

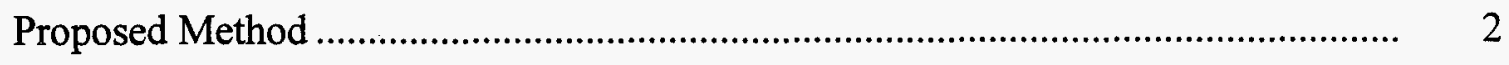

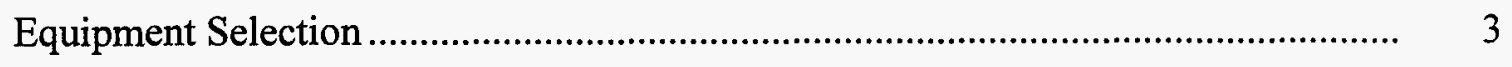

Modifications to the Equipment...............................................................................

Calibration of the Equipment..................................................................................

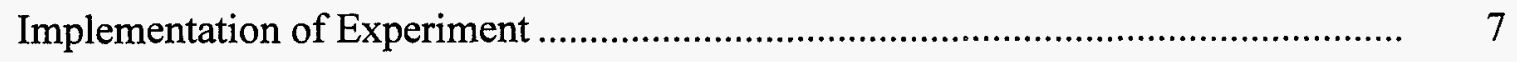

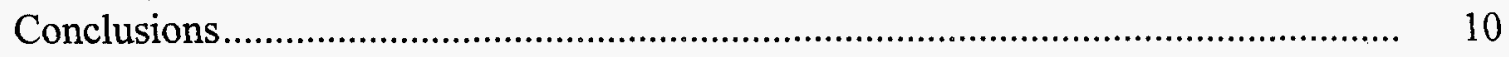

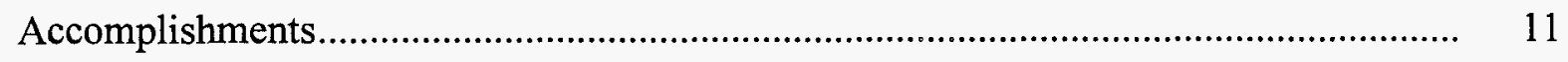

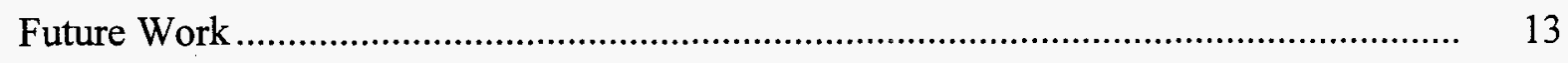

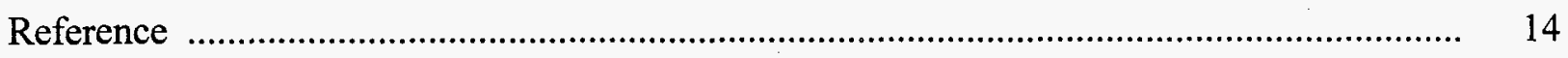

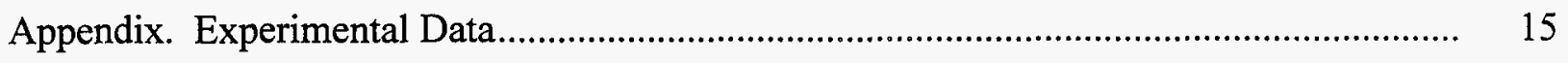




\section{ILLUSTRATIONS}

Figure

Page

$1 \quad$ Focusability of Real and Ideal Laser Beam...................................................

2 Laserscope Operation in Raw Beam and Focused Beam Modes ......................... 5

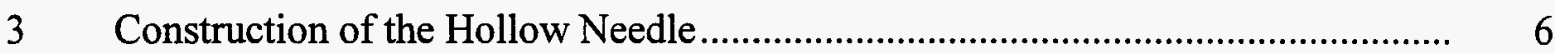

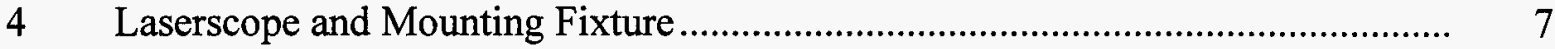

5 Determination of Beam Radius by Laserscope .............................................. 9

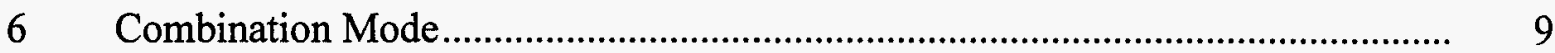

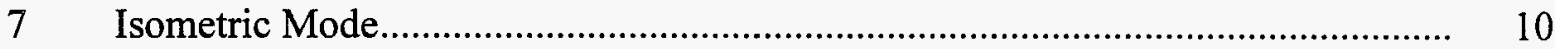

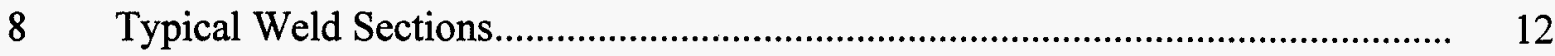

$9 \quad$ Average Weld Penetration Versus Beam Quality ............................................ 13

\section{TABLES}

Number

Page

1 Experimental Data From Four Studies -- Sorted by Average Weld

Penetration Depth for Each Study

$2 \quad$ Experimental Data From Four Studies -- Sorted by $\mathrm{M}^{2}$ for Each Study ................ 17

$3 \quad$ Analysis of Variance, Gasses vs. Weld Penetration Depth and $\mathrm{M}^{2} \ldots \ldots \ldots \ldots \ldots \ldots \ldots . . . . . . . . .18$

$4 \quad$ Regression Analysis, $M^{2}$ vs. Weld Penetration Depth ..................................... 18

$5 \quad$ Analysis of Variance, Gasses vs. Power ........................................................ 18

$6 \quad$ Regression Analysis, Power vs. Weld Penetration Depth and $\mathrm{M}^{2}$........................ 19

7 Analysis of Variance, Type of Lens (New and Used) vs. Weld Penetration Depth and $\mathrm{M}^{2}$ 


\section{ABSTRACT}

The relationship of beam quality and weld depth of penetration was studied to attempt to better quantify the operation of $\mathrm{CO}_{2}$ laser beam welders. Equipment to measure laser beam quality was obtained. The equipment was calibrated using standard apertures. To relate weld penetration and beam quality measurements, it was necessary to force changes in the $\mathrm{CO}_{2}$ laser welder's operation. The chosen experimental variables were laser gas mixture and the use of a group of focusing lenses that had been used in production.

\section{SUMMARY}

The measuring equipment was chosen from state-of-the-art equipment that was available at the time and that could be placed directly in both the focused and unfocused laser beam. The calibration of beam diameter was performed by the use of dimensionally calibrated, sharp edge apertures placed directly above the measuring equipment. Assistance in designing the experiments came from the FM\&T Statistical Services department. The gas mixture experiments were three-factor, fully designed experiments, and the analysis techniques were analysis of variance and regression analysis. The weld coupons were cross sectioned, and measurements were made on the weld nuggets by the FM\&T Analytical Science Laboratory. 


\section{DISCUSSION}

\section{SCOPE AND PURPOSE}

Four objectives were established for this study:

1. Choose the best equipment for making measurements of laser beam quality on high power $\mathrm{CO}_{2}$ laser beam welders.

2. Develop a calibration process for the beam quality measuring equipment.

3. Determine what laser beam parameters affect beam quality and how they should be controlled.

4. Determine if beam quality can be used to quantify weld quality.

Welding with $\mathrm{CO}_{2}$ laser beams is presently controlled with daily weld samples. It would enhance process control if laser beam quality could be routinely measured and related directly to the quality of the weld.

\section{ACTIVITY}

\section{Existing Method}

$\mathrm{CO}_{2}$ laser welders are used in many modern manufacturing processes. The use of the lasers at AlliedSignal Federal Manufacturing \& Technologies (FM\&T) involves the daily check of welder performance with 0.037 and 0.062 in. thick bead-on-plate (B-O-P) weld samples. Welding these samples brackets the machine performance via a functional test that is easily evaluated. The laser is required to penetrate through the thin $(0.037 \mathrm{in}$.) plate but not penetrate through the thick ( 0.067 in.) plate. This daily, before-use, functional check of the laser is done at a specified constant feed rate and laser power. The method has produced satisfactory results, but it would be desirable to further quantify the laser's performance in terms of beam focusability and how that focusability affects weld parameters (most specifically, weld penetration).

\section{Proposed Method}

One very important factor that affects a laser's beam spot diameter is the inherent focusability, or quality, of the raw beam. The formula for this quality factor is

$$
Q=\frac{f \lambda}{\pi w w_{0}}
$$

where $f$ is the focal length of the focusing optics, $\lambda$ is the wavelength of the laser, $w$ is the radius of the raw beam, and $w_{0}$ is the radius of the focused laser beam (see Figure 1). A more 
commonly used term is $\mathrm{M}^{2}$ which is the inverse of $\mathrm{Q} . \mathrm{M}^{2}$ is a dimensionless number and is a measure of how close the actual beam is to a diffraction-limited Gaussian single mode beam. The ideal $\mathrm{M}^{2}$ is equal to 1 . In practice, however, it will always be greater than 1 . Essentially, for a given laser welder, all parameters in the above equation are constant except for focused spot size, $\mathrm{w}_{\mathrm{o}}$, and therefore, $\mathrm{M}^{2}$ is proportional to $\mathrm{w}_{\mathrm{o}}$.

An alternative method for calculating $\mathrm{M}^{2}$ is the use of a curve fit equation of the form

$$
w(z)=w_{0} \sqrt{1+\left[\frac{M^{2} \lambda}{\pi w_{0}^{2}}\right]^{2}\left(z-z_{0}\right)^{2}}
$$

where $w$ is the beam radius at a distance $z$ from the focusing lens. At a distance $z_{0}$ from the lens, the beam radius is a minimum $w_{0}$. Measurements of the focused beam radius are made at various distances from the focusing lens. The equation is then fit to the data using $\mathrm{M}^{2}, \mathrm{w}_{\mathrm{o}}$, and $\mathrm{z}_{\mathrm{o}}$ as the parameters (Ref. 1). Use of the curve fit equation would result in a time savings during actual measurements, as it requires measurements to be made on only the focused beam.

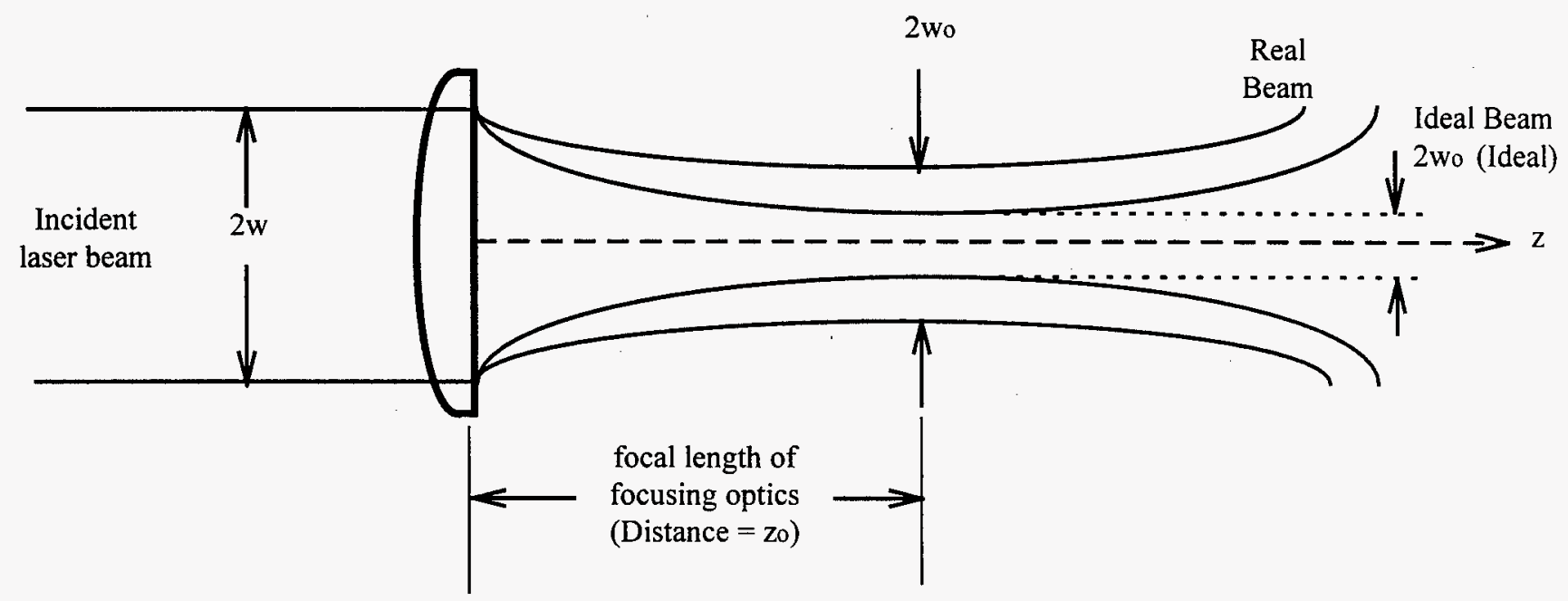

Figure 1. Focusability of Real and Ideal Laser Beam

\section{Equipment Selection}

A search was performed to find the best equipment to measure $\mathrm{M}^{2}$. It was most desirable to find equipment that could accept the beam directly so that additional optics did not have to be used to split the beam. The additional optics would add to the alignment of the setup and would necessitate a beam absorber for the remainder of the beam. 
At the time, the only device that could be found that would meet our needs was the Prometec Laserscope. It had the capability of directly accepting the entire beam, both focused and unfocused (see Figure 2). The Laserscope uses the principle of sampling the beam with a pinhole. The pinhole is drilled near the end of a hollow needle. The needle is mounted on a rotating carrier that steps the rotating needle through the laser beam, thereby scanning the entire cross-sectional area of the beam with a total of 41 scans. A pyroelectric detector is mounted at the axis of the hollow needle, and the sampled beam is reflected through the needle and up to the detector (see Figure 3). The detector signals are amplified, digitized, and then transferred to the computer that is also used to control the monitor.

The Laserscope can accept an unfocused beam with a diameter as large as $50 \mathrm{~mm}$ or as small as $5 \mathrm{~mm}$. (Most of the $\mathrm{CO}_{2}$ welding lasers in the plant have beam diameters of $25 \mathrm{~mm}$ or less.) It can accept focused beams with diameters from $4 \mathrm{~mm}$ to $<100 \mu \mathrm{m}$. A coarse adjustment of the Laserscope to the beam intensity can be made by changing the pinhole size of the needle, which means a physical change of the rotating needle. Fine adjustment is made by changing the internal gain factor. The size of the square measuring window is adjustable so that laser beams of various diameters can be displayed with the best possible resolution.

\section{Modifications to the Equipment}

Once the beam passes through the Laserscope, it has to be dissipated to avoid heating the surface that it contacts. A fixture was made from 1/2 inch aluminum (see Figure 4 ). The beam is diffused by the thin aluminum plate that is mounted at a 53 degree angle. The plate was vapor blasted to provide better diffusion characteristics. During use to make measurements on focused beams, the focal point is at the level of the top of the needle so the diameter of the beam at the plate is great enough that no damage is done to the plate. The plate gets warm with continuous use and a small fan is used under those conditions to cool the plate.

\section{Calibration of the Equipment}

By definition, for Gaussian TEMoo mode, the beam radius of a laser is determined where the intensity has decreased by $1 / \mathrm{e}^{2}$. The Laserscope calculates beam radius in terms of $86 \%\left(1-1 / \mathrm{e}^{2}\right)$ of the laser power. Figure 5a shows an intensity distribution projection. The volume of the distribution is proportional to the power of the laser. The beam cross-sectional area is established by taking into account those measuring points in the intensity distribution whose sum amounts to $86 \%$ of the total for all measuring points and therefore represents a variable proportional to the beam power (Figure $5 b$ ). Figure $5 \mathrm{c}$ shows a projection, and Figure $5 \mathrm{~d}$ shows a contour line display of the cross-sectional area. 


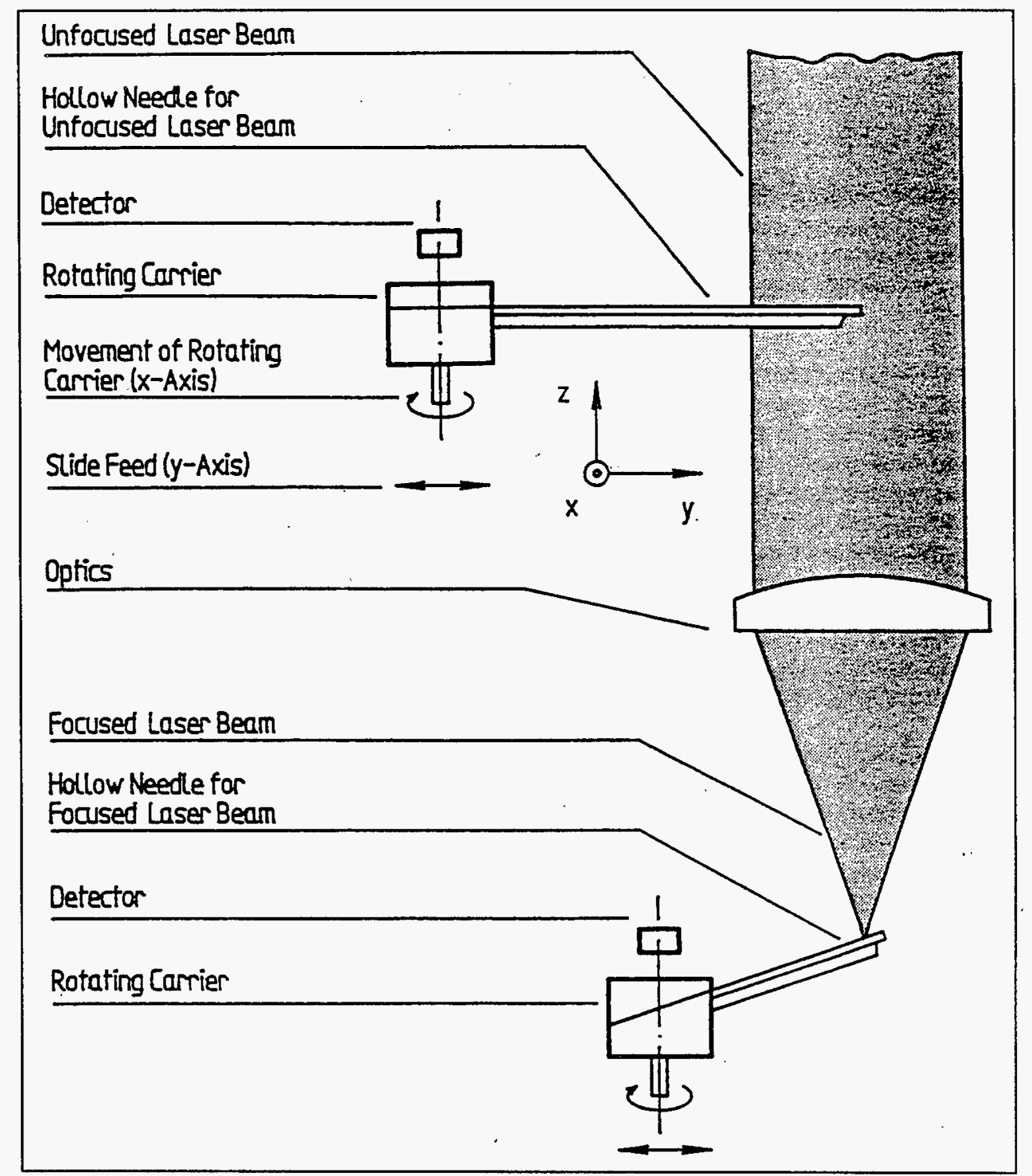

Figure 2. Laserscope Operation in Raw Beam and Focused Beam Modes

The radius is determined by treating the calculated area as a circle. This method is useful only if the beam is rotationally symmetrical, which was a reasonable assumption for the lasers measured in this study. 


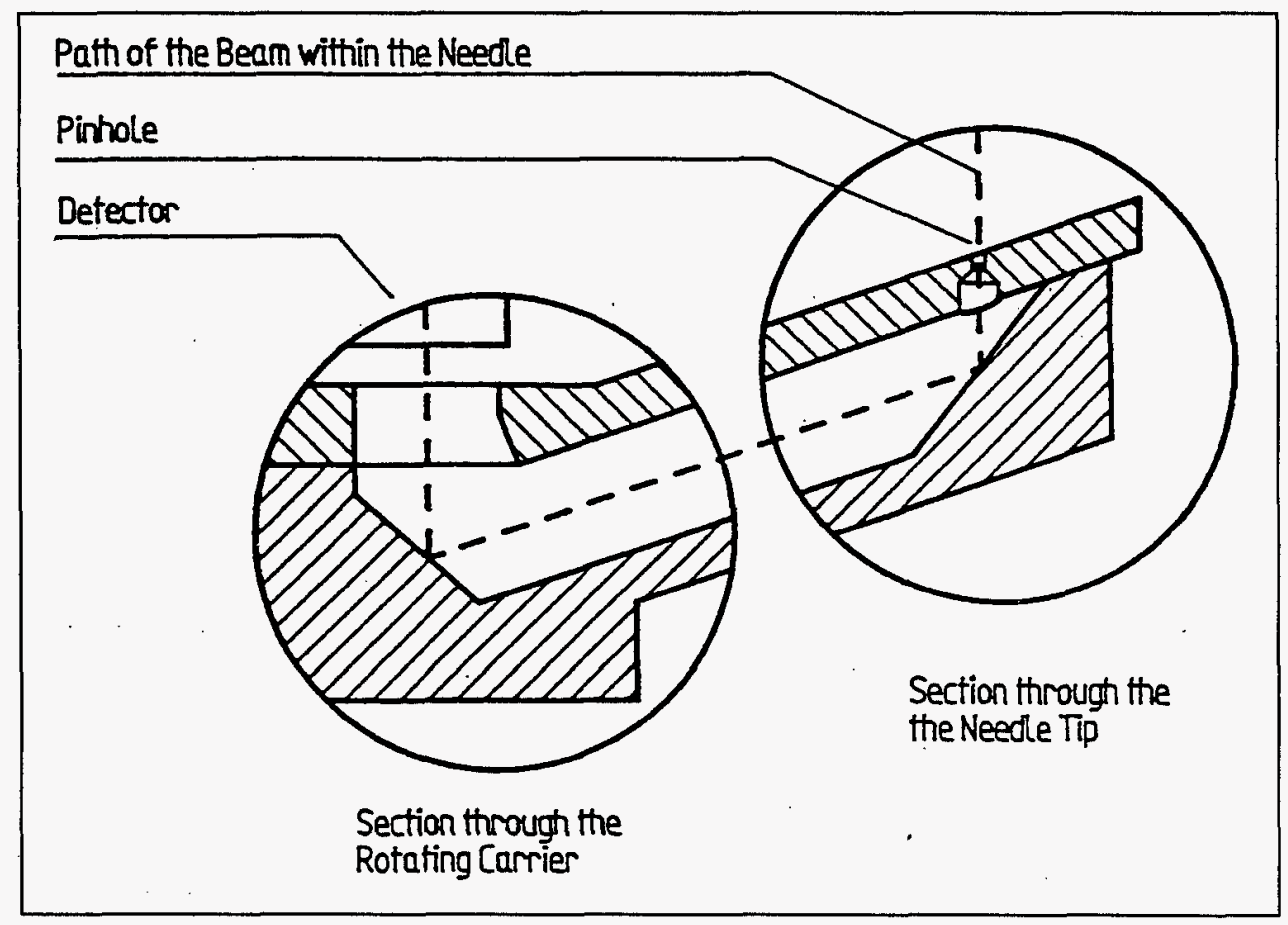

Figure 3. Construction of the Hollow Needle

Calibration of the Laserscope was performed using sharp-edged apertures that had been previously measured by dimensional methods. The apertures were placed on the top edge of the beam entrance port of the equipment. So that the beam was much larger than the aperture, an unfocused laser beam was directed through the aperture and the beam radius was measured using the combination mode of the equipment.

Figure 6 shows this combination mode measurement result, and Figure 7 shows the corresponding isometric mode. Six different apertures were used. The laser beam radius was measured at the $86 \%$ point as defined above. The aperture radius, however, is greater and so, the measured beam radius must be divided by some factor to account for the remainder of the beam that passed through the aperture. The factor was found to be approximately equal to $1-1 / \mathrm{e}^{2}$. Using this factor, the agreement of the calibrated apertures to the instrument data ranged from $0.8 \%$ to $8 \%$. 


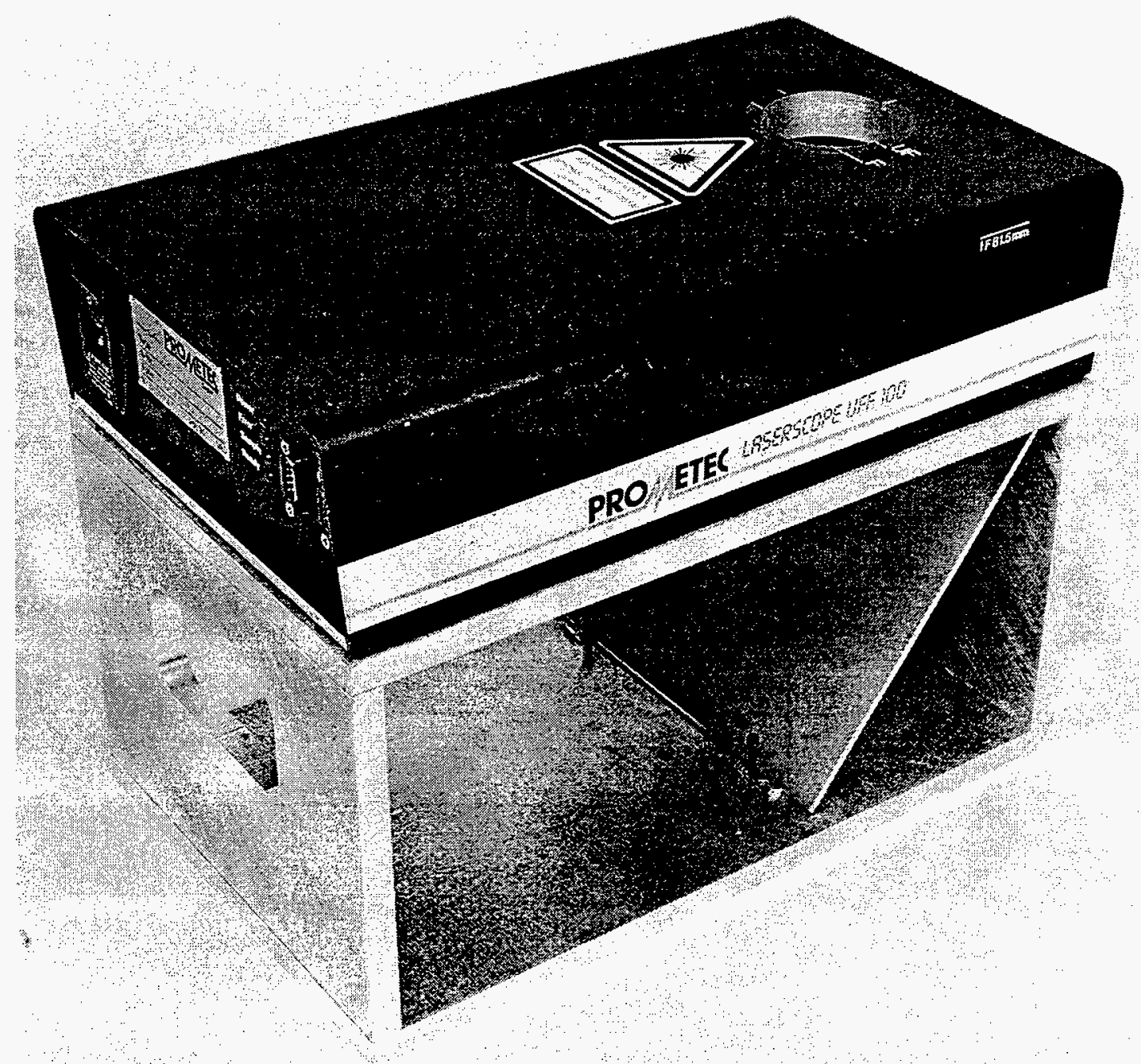

Figure 4. Laserscope and Mounting Fixture

\section{Implementation of Experiment}

Four studies were performed using two different laser welding systems; these studies are identified as follows:

1. Weld System \#1, Study A, was a two-level, three-factor, fully designed experiment (or eight distinct settings). The factors were gas flows of $\mathrm{He}, \mathrm{CO}_{2}$, and $\mathrm{N}_{2}$. The levels were 60 and 140 for $\mathrm{He}, 50$ and 110 for $\mathrm{CO}_{2}$, and 60 and 100 for $\mathrm{N}_{2}$. These levels represent relative gas flows of the approximate minimum and maximum limits of practical adjustment. The power was held constant at 600 Watts by adjusting resonator current to offset the power change caused by the gas flow change. Weld speed was held constant at $60 \mathrm{in} / \mathrm{min}$. Eight stainless steel coupons were obtained from one sheet of stainless steel. This sheet of stainless steel was used for all coupons throughout the study. One coupon was used for each of the eight gas settings, and four B-O-P 
welds were made on each coupon. Before each coupon was welded, the average $\mathrm{M}^{2}$ value was obtained.

2. Weld System \#2, Study B, was a two-level, three-factor, fully designed experiment (eight distinct settings) and one at the normal settings. The factors were gas flows of $\mathrm{He}, \mathrm{CO}_{2}$, and $\mathrm{N}_{2}$. The levels were 40 and 80 for $\mathrm{He}, 50$ and 110 for $\mathrm{CO}_{2}$, and 60 and 100 for $\mathrm{N}_{2}$. The normal settings are 52,79 , and 92 for $\mathrm{He}, \mathrm{CO}_{2}$, and $\mathrm{N}_{2}$, respectively. The power was held constant at 600 Watts by adjusting resonator current, and weld speed was held constant at $60 \mathrm{in} / \mathrm{min}$. Nine stainless steel coupons were used in this study. One coupon was used for each of the nine different gas settings, and three B-O-P welds were made on each coupon. Before each coupon was welded, the average $\mathrm{M}^{2}$ value was obtained.

3. Weld System \#2, Study C, was a two-level, three factor, fully designed experiment (eight distinct settings) and one at the normal settings. The factors were gas flows of $\mathrm{He}, \mathrm{CO}_{2}$, and $\mathrm{N}_{2}$. The levels were 40 and 80 for $\mathrm{He}, 50$ and 110 for $\mathrm{CO}_{2}$, and 60 and 100 for $\mathrm{N}_{2}$. The normal settings are 52,79 , and 92 for $\mathrm{He}, \mathrm{CO}_{2}$, and $\mathrm{N}_{2}$, respectively. The weld speed was held constant at $60 \mathrm{in} / \mathrm{min}$. The power was set at $600 \mathrm{Watts}$ at normal setting and was not adjusted when gas settings were changed, but power was recorded when the gas settings were changed. Nine stainless steel coupons were used in this study. One coupon was used for each of the nine different gas settings, and three B-O-P welds were made on each coupon. Before each coupon was welded, the average $\mathrm{M}^{2}$ value was obtained.

4. Weld System \#2, Study D, used seven different lenses. Six lenses had been used and rejected from the production line, and one was a new and acceptable lens. The gasses were set at normal settings $\left(52,79\right.$, and 92 for $\mathrm{He}, \mathrm{CO}_{2}$, and $\mathrm{N}_{2}$, respectively), power was set at $600 \mathrm{Watts}$, and weld speed was set at $60 \mathrm{in} / \mathrm{min}$. Seven stainless steel coupons were used in this study. One coupon was used for each of the seven different lenses, and three B-O-P welds were made on each coupon. Before each coupon was welded, the average $\mathrm{M}^{2}$ value was obtained for each lens.

The welded coupons were taken to the FM\&T Analytical Science Laboratory. The coupons were sectioned, polished, etched, and each weld was measured for depth and width using a calibrated optical comparator. Photographs of some of the weld sections were taken with a magnification of 50X (see Figure 8). The data was used to first calculate the average and standard deviation of weld depth for each coupon. The results were sorted by study and average depth and are listed in Table 1 in the Appendix. The results also were sorted by study and $\mathrm{M}^{2}$; those results are listed in Table 2. 


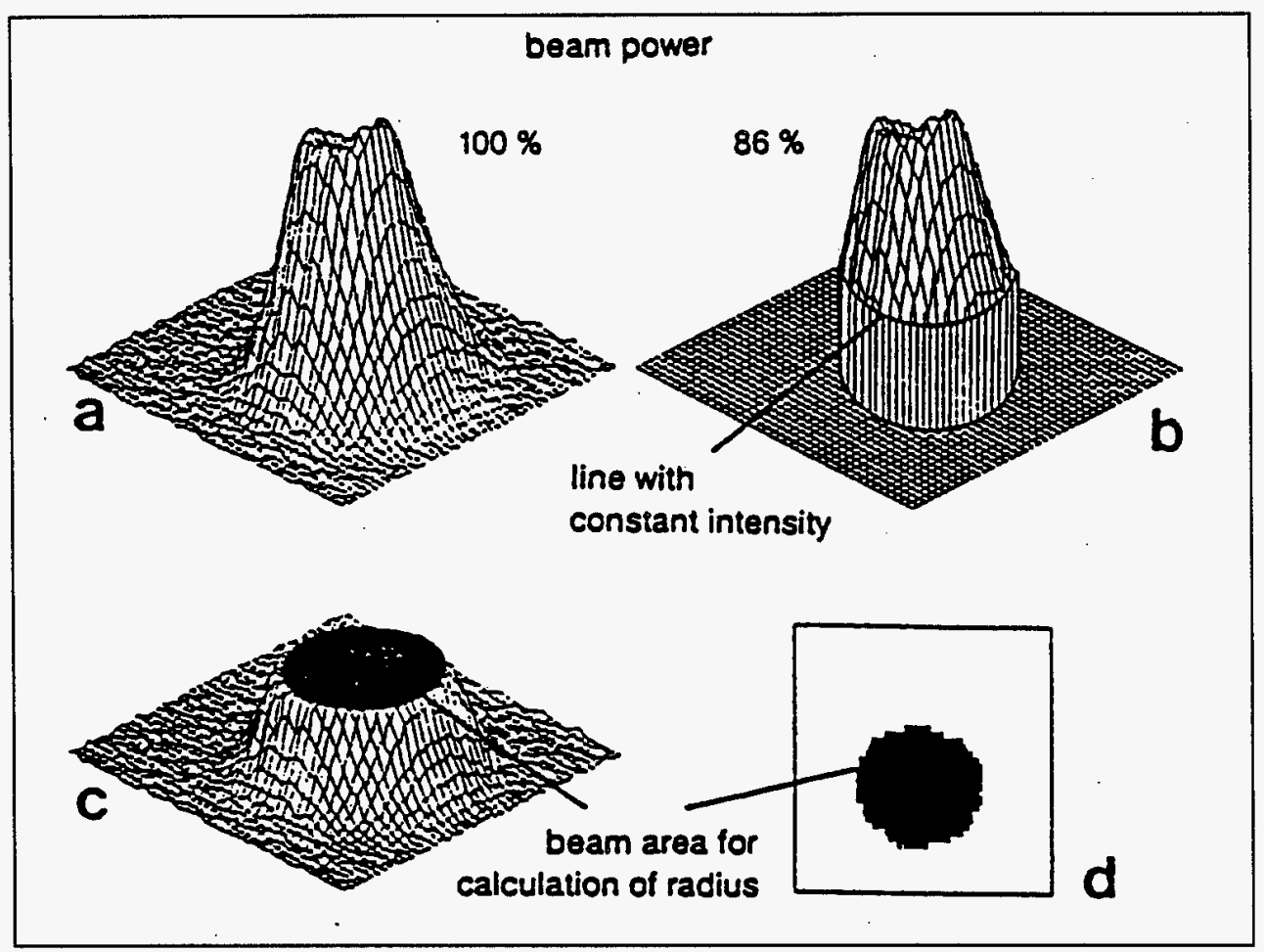

Figure 5. Determination of Beam Radius by Laserscope

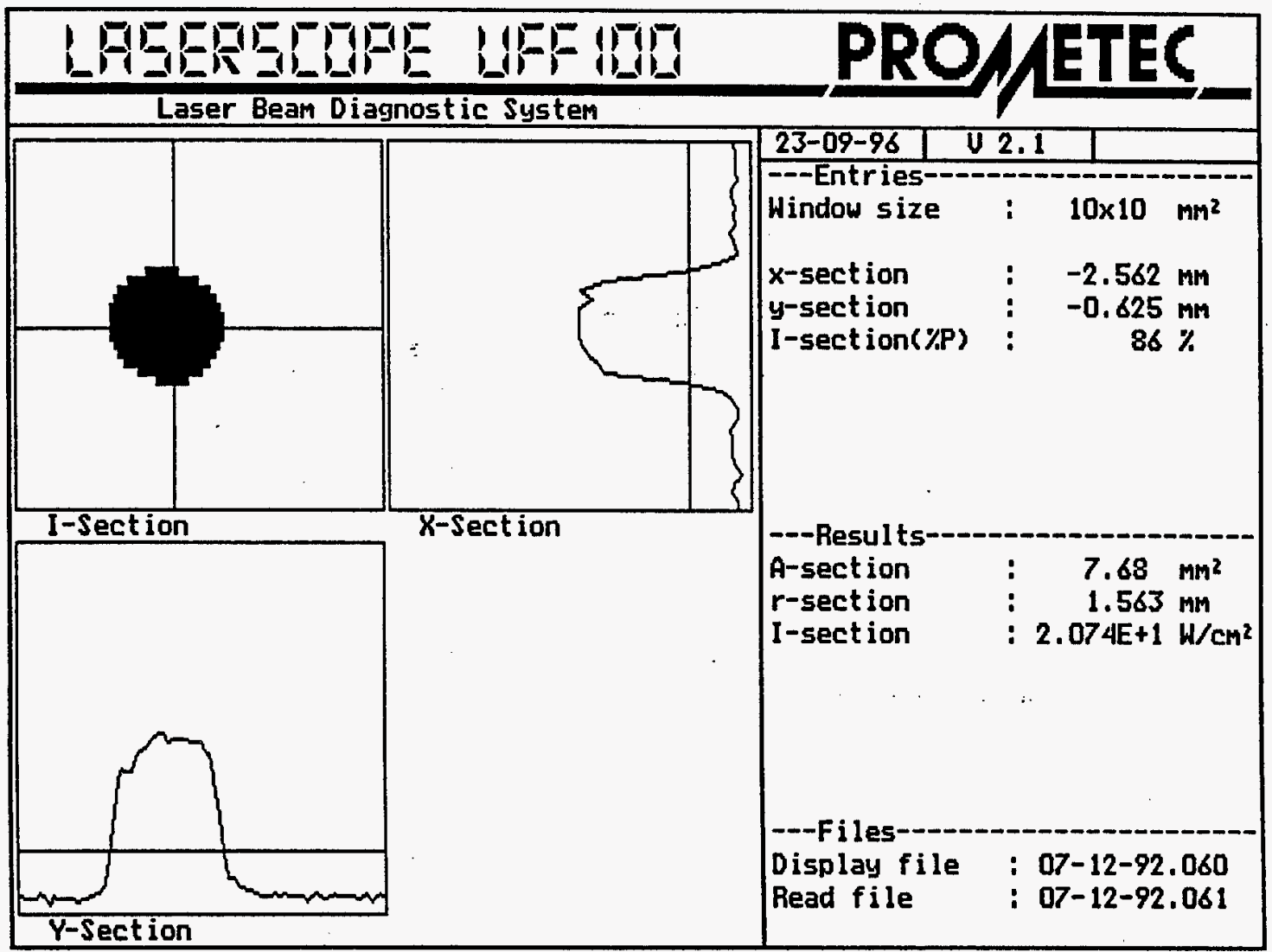

Figure 6. Combination Mode 


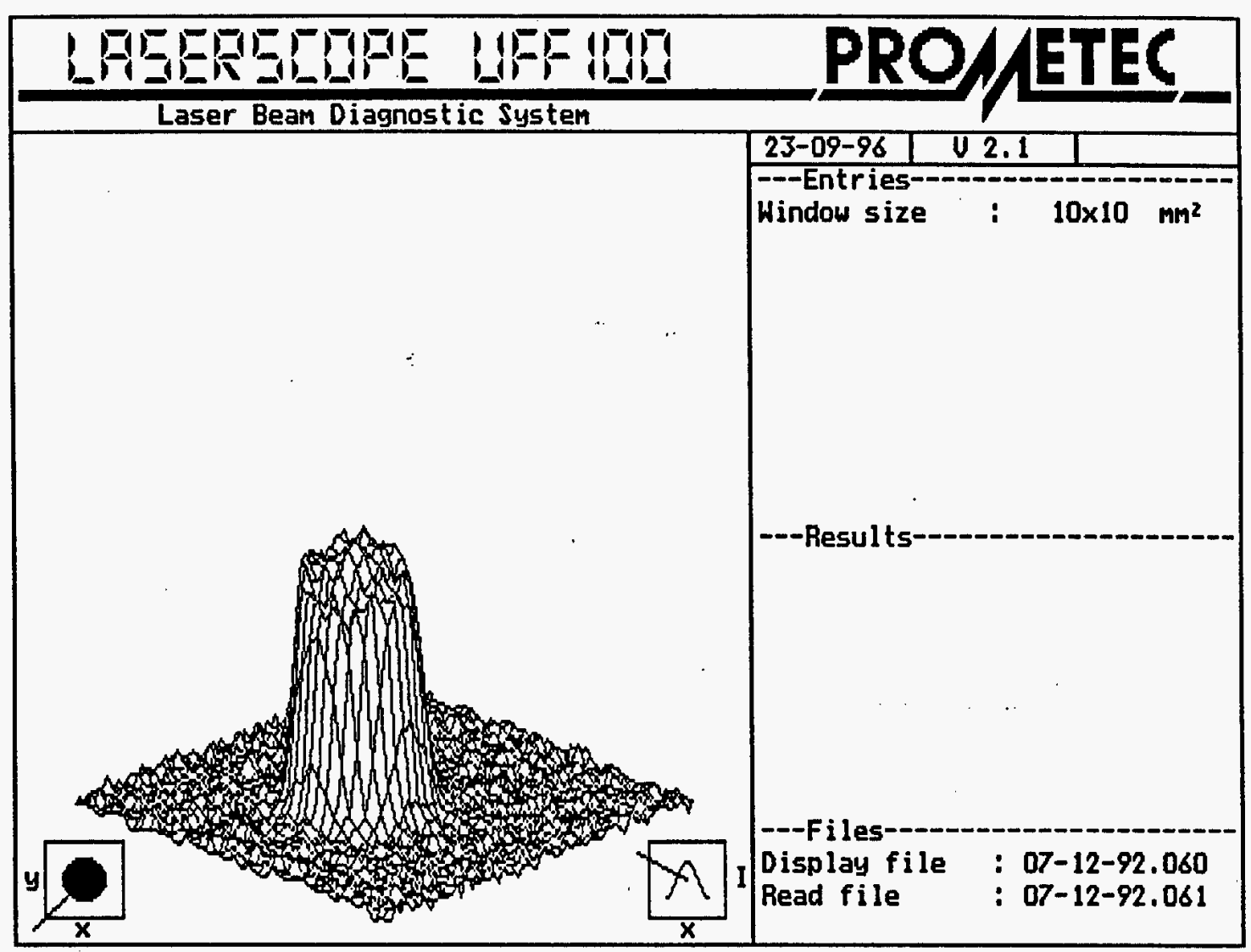

Figure 7. Isometric Mode

\section{Conclusions}

The data was analyzed to determine if gasses have an effect on either average weld penetration depth or $\mathrm{M}^{2}$, for Studies A, B, and C. The analysis technique is called analysis of variance. The analysis indicated the following:

1. The analysis did not detect a significant effect due to gasses on depth for studies A and B. $\mathrm{N}_{2}$ indicated an effect on depth for Study C. If you look at Table 1, Study C, high values of $\mathrm{N}_{2}$ and power give larger values for depth. The effect is due to power, not $\mathrm{N}_{2}$. The results are summarized in Table 3.

2. The analysis detected significant effects due to gasses on $\mathrm{M}^{2}$ for studies $\mathrm{A}$ and $\mathrm{C}$ but not on Study B. These results are summarized in Table 3. Studies A and B were similar studies but on different weld systems. Why one shows effect on $\mathrm{M}^{2}$ due to gasses and the other no effect could mean there is another factor(s) effecting $\mathrm{M}^{2}$.

Regression analysis was performed on the average weld penetration depth and $\mathrm{M}^{2}$ on Studies $\mathrm{A}$, $\mathrm{B}$, and $\mathrm{D}$, to determine if there is significant correlation. These analyses did not detect 
significant correlation between depth and $\mathrm{M}^{2}$ on any of the studies. The results are given in Table 4.

Analysis of variance was performed on Study $\mathrm{C}$ to determine if the gasses have a significant effect on the power reading. This analysis failed to detect a significant effect. The results are displayed in Table 5.

Regression analysis was performed on the average weld depth and $\mathrm{M}^{2}$ versus power, on Study $\mathrm{C}$, to determine if there is significant correlation. This analysis indicated there is significant correlation between power and weld depth but not between $\mathrm{M}^{2}$ and power. The results are given in Table 6.

Analysis of variance was performed on Study D to determine if there is a significant difference between type of lens (new and old lens) on weld depth and $\mathrm{M}^{2}$. This analysis failed to detect a significant difference in type of lens for either weld depth or $\mathrm{M}^{2}$. These results are listed in Table 7 .

A plot of the average weld depth as a function of $\mathrm{M}^{2}$ for data from all the studies on the two different laser welders is shown in Figure 9. The two different lasers generated two clusters of data that appear to show a relationship between weld depth and $\mathrm{M}^{2}$, although no relationship was substantiated by statistical analysis.

\section{ACCOMPLISHMENTS}

The analyses of data indicate the following:

1. There is not a significant effect on average weld penetration depth due to gas settings. This supports the concept that laser is a robust process for welding application with respect to gas settings.

2. There may be an effect on $\mathbf{M}^{2}$ readings due to gas settings; results are inconclusive.

3. There is not a significant relationship between average weld penetration depth and $\mathbf{M}^{2}$.

4. As gas settings are changed, the power will change, but we could not find a relationship between gas settings and power change.

5. There is a strong relationship between power and weld penetration depth.

6. There is no relationship between power and $\mathbf{M}^{2}$.

7. There was no difference between new and old lenses with respect to weld penetration depth and $\mathrm{M}^{2}$ value.

Although a significant relationship between weld penetration and $\mathrm{M}^{2}$ could not be found, an obvious use for the Laserscope is in the monitoring of the general state of optimization of a laser weld system. The Laserscope can be used to document laser beam profile changes with time and will be a valuable tool in bringing a laser weld system back on line after required maintenance. 

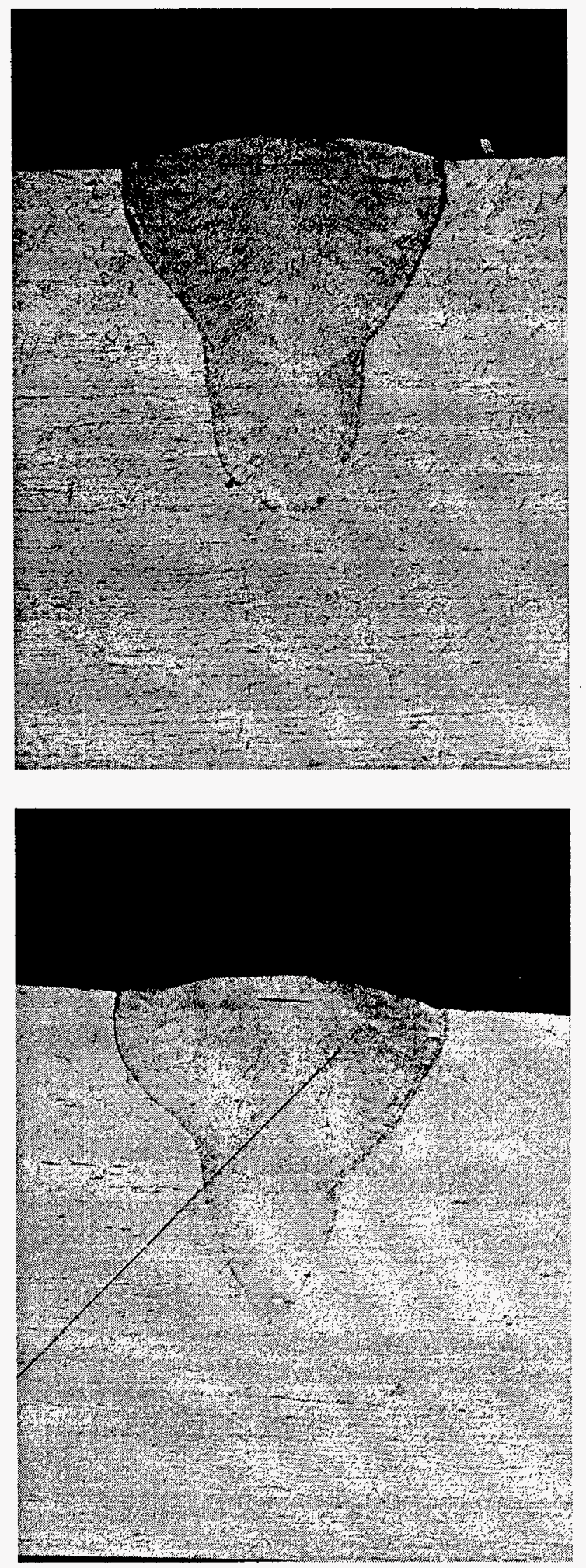

Figure 8. Typical Weld Sections 


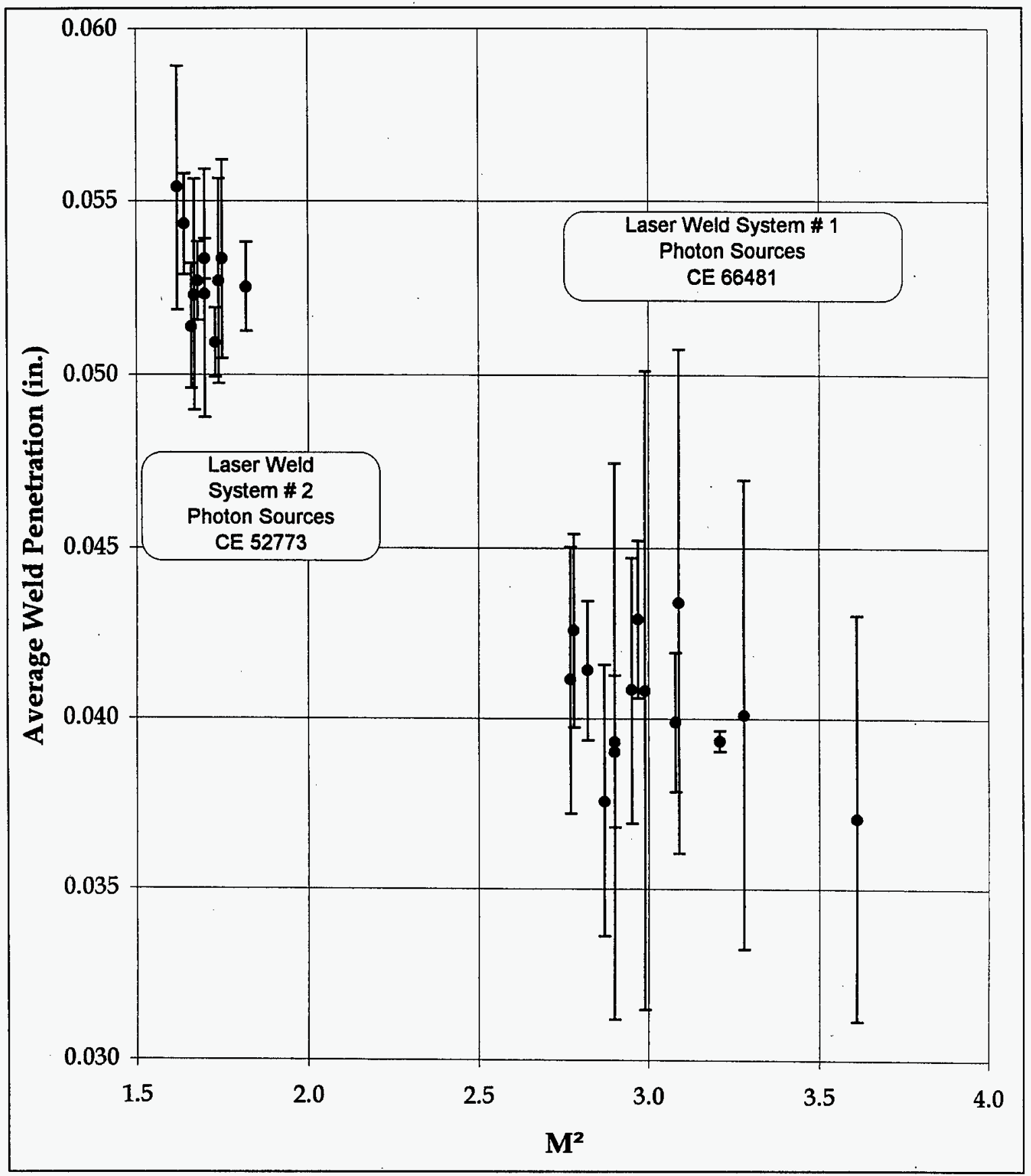

Figure 9. Average Weld Penetration Versus Beam Quality (power was $600 \mathrm{~W}$ for both lasers)

\section{FUTURE WORK}

Additional measurements of $\mathrm{M}^{2}$ on laser weld systems other than the two that were available for this study would yield more data which may show a relationship to weld penetration. An alternative study which might be possible would be to change the beam quality by using lenses with varying focal lengths, suggested by Ref. 1 , and observing the effects on weld penetration. 


\section{REFERENCE}

1. M. Essien and P. W. Fuerschbach, Beam Characterization of a Materials Processing $\mathrm{CO}_{2}$ Laser. Welding Journal, February 1996, pp. 47-54. 
APPENDIX

\section{Experimental Data}


Table 1. Experimental Data From Four Studies -- Sorted by Average Weld Penetration Depth for Each Study

Weld Depth

\begin{tabular}{|c|c|c|c|c|c|c|c|c|c|}
\hline Study & Lens & $\mathrm{He}$ & $\mathrm{CO}_{2}$ & $\mathrm{~N}_{2}$ & Power & $\mathrm{M}^{2}$ & XBAR & Sigma & No. \\
\hline A & NEW & 60 & 50 & 60 & 600 & 3.21 & 0.0394 & 0.0016 & 4 \\
\hline A & NEW & 140 & 110 & 60 & 600 & 3.08 & 0.0399 & 0.0015 & 4 \\
\hline A & NEW & 60 & 110 & 60 & 600 & 2.95 & 0.0408 & 0.0017 & 4 \\
\hline A & NEW & 60 & 110 & 100 & 600 & 2.77 & 0.0411 & 0.0019 & 4 \\
\hline A & NEW & 140 & 110 & 100 & 600 & 2.82 & 0.0414 & 0.0012 & 4 \\
\hline A & NEW & 140 & 50 & 100 & 600 & 2.78 & 0.0426 & 0.0013 & 4 \\
\hline A & NEW & 60 & 50 & 100 & 600 & 2.97 & 0.0429 & 0.0010 & 4 \\
\hline A & NEW & 140 & 50 & 60 & 600 & 3.09 & 0.0434 & 0.0032 & 4 \\
\hline B & NEW & 80 & 110 & 100 & 600 & 1.66 & 0.0514 & 0.0009 & 3 \\
\hline B & NEW & 40 & 110 & 100 & 600 & 1.67 & 0.0523 & 0.0017 & 3 \\
\hline B & NEW & 40 & 50 & 100 & 600 & 1.70 & 0.0523 & 0.0018 & 3 \\
\hline B & NEW & 40 & 50 & 60 & 600 & 1.82 & 0.0525 & 0.0006 & 3 \\
\hline B & NEW & 80 & 50 & 60 & 600 & 1.74 & 0.0527 & 0.0015 & 3 \\
\hline B & NEW & 80 & 110 & 60 & 600 & 1.68 & 0.0527 & 0.0006 & 3 \\
\hline B & NEW & 40 & 110 & 60 & 600 & 1.70 & 0.0533 & 0.0003 & 3 \\
\hline B & NEW & 52 & 79 & 92 & 600 & 1.64 & 0.0543 & 0.0007 & 3 \\
\hline B & NEW & 80 & 50 & 100 & 600 & 1.62 & 0.0554 & 0.0018 & 3 \\
\hline $\mathrm{C}$ & NEW & 40 & 110 & 60 & 480 & 1.62 & 0.0429 & 0.0012 & 3 \\
\hline $\mathrm{C}$ & NEW & 40 & 50 & 60 & 490 & 1.84 & 0.0435 & 0.0023 & 3 \\
\hline $\mathrm{C}$ & NEW & 80 & 50 & 60 & 530 & 1.74 & 0.0473 & 0.0007 & 3 \\
\hline $\mathrm{C}$ & NEW & 80 & 110 & 60 & 520 & 1.60 & 0.0481 & 0.0018 & 3 \\
\hline $\mathrm{C}$ & NEW & 40 & 110 & 100 & 560 & 1.73 & 0.0509 & 0.0005 & 3 \\
\hline $\mathrm{C}$ & NEW & 52 & 79 & 92 & 600 & 1.73 & 0.0520 & 0.0010 & 3 \\
\hline $\mathrm{C}$ & NEW & 40 & 50 & 100 & 600 & 1.75 & 0.0533 & 0.0014 & 3 \\
\hline $\mathrm{C}$ & NEW & 80 & 110 & 100 & 620 & 1.77 & 0.0543 & 0.0021 & 3 \\
\hline $\mathrm{C}$ & NEW & 80 & 50 & 100 & 640 & 1.74 & 0.0557 & 0.0025 & 3 \\
\hline D & OLD2 & 52 & 79 & 92 & 600 & 2.15 & 0.0498 & 0.0009 & 3 \\
\hline D & NEW & 52 & 79 & 92 & 600 & 1.72 & 0.0499 & 0.0013 & 3 \\
\hline D & OLD1 & 52 & 79 & 92 & 600 & 1.76 & 0.0507 & 0.0016 & 3 \\
\hline D & OLD3 & 52 & 79 & 92 & 600 & 1.69 & 0.0534 & 0.0027 & 3 \\
\hline D & OLD6 & 52 & 79 & 92 & 600 & 1.80 & 0.0545 & 0.0034 & 3 \\
\hline D & OLD4 & 52 & 79 & 92 & 600 & 1.67 & 0.0547 & 0.0035 & 3 \\
\hline D & OLD5 & 52 & 79 & 92 & 600 & 1.73 & 0.0551 & 0.0039 & 3 \\
\hline
\end{tabular}


Table 2. Experimental Data From Four Studies -- Sorted by $\mathbf{M}^{2}$ for Each Study

Weld Depth

\begin{tabular}{|c|c|c|c|c|c|c|c|c|c|}
\hline Study & Lens & $\mathrm{He}$ & $\mathrm{CO}_{2}$ & $\mathrm{~N}_{2}$ & Power & $\mathrm{M}^{2}$ & XBAR & Sigma & No. \\
\hline A & NEW & 60 & 110 & 100 & 600 & 2.77 & 0.0411 & 0.0019 & 4 \\
\hline A & NEW & 140 & 50 & 100 & 600 & 2.78 & 0.0426 & 0.0013 & 4 \\
\hline A & NEW & 140 & 110 & 100 & 600 & 2.82 & 0.0414 & 0.0012 & 4 \\
\hline A & NEW & 60 & 110 & 60 & 600 & 2.95 & 0.0408 & 0.0017 & 4 \\
\hline A & NEW & 60 & 50 & 100 & 600 & 2.97 & 0.0429 & 0.0010 & 4 \\
\hline A & NEW & 140 & 110 & 60 & 600 & 3.08 & 0.0399 & 0.0015 & 4 \\
\hline A & NEW & 140 & 50 & 60 & 600 & 3.09 & 0.0434 & 0.0032 & 4 \\
\hline A & NEW & 60 & 50 & 60 & 600 & 3.21 & 0.0394 & 0.0016 & 4 \\
\hline B & NEW & 80 & 50 & 100 & 600 & 1.62 & 0.0554 & 0.0018 & 3 \\
\hline B & NEW & 52 & 79 & 92 & 600 & 1.64 & 0.0543 & 0.0007 & 3 \\
\hline B & NEW & 80 & 110 & 100 & 600 & 1.66 & 0.0514 & 0.0009 & 3 \\
\hline B & NEW & 40 & 110 & 100 & 600 & 1.67 & 0.0523 & 0.0017 & 3 \\
\hline B & NEW & 80 & 110 & 60 & 600 & 1.68 & 0.0527 & 0.0006 & 3 \\
\hline B & NEW & 40 & 50 & 100 & 600 & 1.70 & 0.0523 & 0.0018 & 3 \\
\hline B & NEW & 40 & 110 & 60 & 600 & 1.70 & 0.0533 & 0.0003 & 3 \\
\hline B & NEW & 80 & 50 & 60 & 600 & 1.74 & 0.0527 & 0.0015 & 3 \\
\hline B & NEW & 40 & 50 & 60 & 600 & 1.82 & 0.0525 & 0.0006 & 3 \\
\hline $\mathrm{C}$ & NEW & 80 & 110 & 60 & 520 & 1.60 & 0.0481 & 0.0018 & 3 \\
\hline $\mathrm{C}$ & NEW & 40 & 110 & 60 & 480 & 1.62 & 0.0429 & 0.0012 & 3 \\
\hline $\mathrm{C}$ & NEW & 40 & 110 & 100 & 560 & 1.73 & 0.0509 & 0.0005 & 3 \\
\hline $\mathrm{C}$ & NEW & 52 & 79 & 92 & 600 & 1.73 & 0.0520 & 0.0010 & 3 \\
\hline $\mathrm{C}$ & NEW & 80 & 50 & 60 & 530 & 1.74 & 0.0473 & 0.0007 & 3 \\
\hline $\mathrm{C}$ & NEW & 80 & 50 & 100 & 640 & 1.74 & 0.0557 & 0.0025 & 3 \\
\hline $\mathrm{C}$ & NEW & 40 & 50 & 100 & 600 & 1.75 & 0.0533 & 0.0014 & 3 \\
\hline C & NEW & 80 & 110 & 100 & 620 & 1.77 & 0.0543 & 0.0021 & 3 \\
\hline $\mathrm{C}$ & NEW & 40 & 50 & 60 & 490 & 1.84 & 0.0435 & 0.0023 & 3 \\
\hline D & OLD4 & 52 & 79 & 92 & 600 & 1.67 & 0.0547 & 0.0035 & 3 \\
\hline D & OLD3 & 52 & 79 & 92 & 600 & 1.69 & 0.0534 & 0.0027 & 3 \\
\hline D & NEW & 52 & 79 & 92 & 600 & 1.72 & 0.0499 & 0.0013 & 3 \\
\hline D & OLD5 & 52 & 79 & 92 & 600 & 1.73 & 0.0551 & 0.0039 & 3 \\
\hline D & OLD1 & 52 & 79 & 92 & 600 & 1.76 & 0.0507 & 0.0016 & 3 \\
\hline D & OLD6 & 52 & 79 & 92 & 600 & 1.80 & 0.0545 & 0.0034 & 3 \\
\hline $\mathrm{D}$ & OLD2 & 52 & 79 & 92 & 600 & 2.15 & 0.0498 & 0.0009 & 3 \\
\hline
\end{tabular}


Table 3. Analysis of Variance, Gasses vs. Weld Penetration Depth and $\mathbf{M}^{2}$

\begin{tabular}{|c|c|c|c|c|c|c|}
\hline \multicolumn{7}{|c|}{$\begin{array}{l}\text { * means interaction term } \\
\text { Yes means significant effect at } 5 \% \text { level; No means did not detect significant effect. }\end{array}$} \\
\hline & $\begin{array}{l}\text { Study A } \\
\text { Depth }\end{array}$ & $\mathrm{M}^{2}$ & $\begin{array}{l}\text { Study B } \\
\text { Depth }\end{array}$ & $M^{2}$ & $\begin{array}{l}\text { Study C } \\
\text { Depth }\end{array}$ & $\mathbf{M}^{2}$ \\
\hline $\mathrm{He}$ & No & Yes & No & No & No & Yes \\
\hline $\mathrm{CO}_{2}$ & No & Yes & No & No & No & Yes \\
\hline $\mathrm{N}_{2}$ & No & Yes & No & No & Yes & Yes \\
\hline $\mathrm{He}^{*} \mathrm{CO}_{2}$ & No & Yes & No & No & No & Yes \\
\hline $\mathrm{He}^{*} \mathrm{~N}_{2}$ & No & Yes & No & No & No & Yes \\
\hline $\mathrm{CO} 2^{*} \mathrm{~N}_{2}$ & No & No & No & No & No & Yes \\
\hline
\end{tabular}

Table 4. Regression Analysis, $\mathbf{M}^{2}$ vs. Weld Penetration Depth

No means there is not significant correlation.

\begin{tabular}{|c|c|c|}
\hline $\begin{array}{l}\text { Study A } \\
\text { Depth }\end{array}$ & $\begin{array}{l}\text { Study B } \\
\text { Depth }\end{array}$ & $\begin{array}{l}\text { Study C } \\
\text { Depth }\end{array}$ \\
\hline No & No & No \\
\hline
\end{tabular}

Table 5. Analysis of Variance, Gasses vs. Power

* means interaction term

Yes means significant effect at $5 \%$ level;

No means did not detect significant effect.

Study C

Power

\begin{tabular}{|c|c|}
\hline $\mathrm{He}$ & $\mathrm{No}$ \\
$\mathrm{CO}_{2}$ & $\mathrm{No}$ \\
$\mathrm{N}_{2}$ & $\mathrm{No}$ \\
$\mathrm{He}^{*} \mathrm{CO}_{2}$ & $\mathrm{No}$ \\
$\mathrm{He}^{*} \mathrm{~N}_{2}$ & $\mathrm{No}$ \\
$\mathrm{CO}_{2}{ }^{*} \mathrm{~N}_{2}$ & $\mathrm{No}$ \\
\hline
\end{tabular}


Table 6. Regression Analysis, Power vs. Weld Penetration Depth and $\mathbf{M}^{2}$

Yes, there was significant correlation;

No, there is not significant correlation. Study C

Depth $\quad \mathbf{M}^{2}$

Power Yes $\quad$ No

Table 7. Analysis of Variance, Type of Lens (New and Used) vs. Weld Penetration Depth and $\mathrm{M}^{2}$

No means did not detect significant effect at the $5 \%$ level.

\begin{tabular}{ccc} 
& \multicolumn{1}{c}{$\begin{array}{c}\text { Study D } \\
\text { Depth }\end{array}$} & $\mathrm{M}^{2}$ \\
\cline { 2 - 3 } Type & No & No \\
\cline { 2 - 3 } & &
\end{tabular}


M97053645

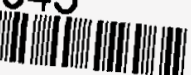

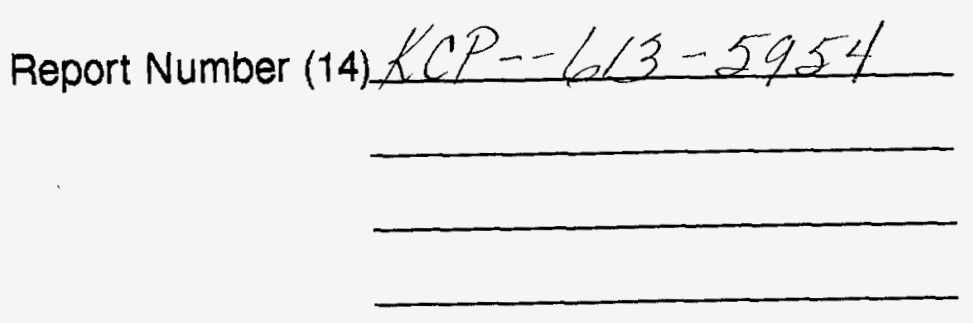

subl. Date (11) 199706

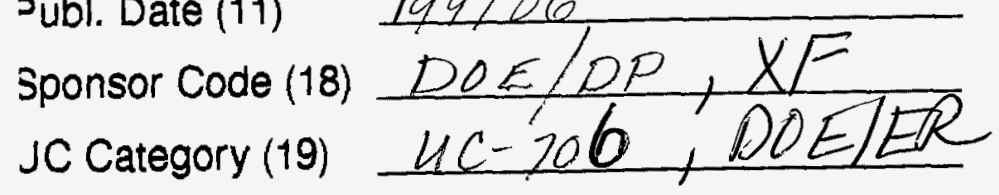

DOE 